\title{
Use of high-dose oxycodone hydrochloride in patients with visceral and neuropathic pain
}

\author{
Jakub Kucharz ${ }^{1,2}$, Iwona Filipczak-Bryniarska ${ }^{3,4}$, Anna Michalowska-Kaczmarczyk ${ }^{1}$, Roman M. Herman², \\ Krzysztof Krzemieniecki ${ }^{1,5}$ \\ ${ }^{1}$ Department of Clinical Oncology, University Hospital in Krakow, Krakow, Poland \\ 2Department of Experimental and Clinical Surgery, Jagiellonian University Medical College, Krakow, Poland \\ ${ }^{3}$ Department of Palliative Medicine, Department of Internal Medicine and Geriatrics, University Hospital in Krakow, Krakow, Poland \\ ${ }^{4}$ Department of Pain Treatment and Palliative Care, Jagiellonian University Medical College, Krakow, Poland \\ ${ }^{5}$ Department of Oncology, Jagiellonian University Medical College, Krakow, Poland
}

Contemp Oncol (Pozn) 2014; 19 (3): 257-259 DOI: $10.5114 /$ wo.2015.52662

\section{Case study}

The patient, R. A., aged 39, male, was referred to the Department of Oncology at the University Hospital in Krakow in March 2013 due to caecal cancer with liver, peritoneal, and abdominal lymph nodes metastases.

The disease was diagnosed in February 2013 when the patient underwent a diagnostic procedure because of abdominal pain that had started approximately three months earlier and weight loss (approx. $10 \mathrm{~kg}$ in three months). Based on histopathological examination of samples taken during colonoscopy, an adenocarcinoma of the cecum was diagnosed. The imaging examinations revealed the presence of pathologically enlarged lymph nodes in the area of ileocaecal vessels and metastatic lesions in the liver (segment 4 and the boundary between segments 4 and 1 ). The patient was qualified for palliative surgery: a right-sided hemicolectomy was performed, with intraoperative biopsy of the hepatic lesions; the presence of metastases in the vesicorectal space was also confirmed. The postoperative histological examination revealed poorly differentiated adenocarcinoma (G3), the stage being determined as IVB (pT3N2bM1b). The patient was referred to the Department of Oncology at the University Hospital for further treatment. The patient did not report any pain, and his performance status was described as good (ECOG 0). Of note was chronic hepatitis B and well-controlled primary hypertension in his medical history. Due to the advanced stage of the disease, the patient was qualified for palliative chemotherapy according to the FOLFIRI regimen (5-fluorouracil, leucovorin, irinotecan).

A systemic treatment was started, which was well tolerated by the patient. The treatment was continued until the sixth series, with control imaging examinations performed after the last one. Computed tomography of the abdomen revealed hepatomegaly and progression of metastatic lesions in the liver, the peritoneum, and the lymph nodes around the celiac trunk and the ileocecal vessels. A decision was made to launch a second-line chemotherapy regimen, FOLFOX4 (5-fluorouracil, leucovorin, oxaliplatin) + bevacizumab. The patient tolerated the treatment well; however, in the course of treatment, they reported an incidence of dull, diffuse, poorly localised pain of a gripping and cramp-like nature. According to the self-assessment of the patient, the pain intensity on the NRS scale reached the level of 3/10. Meloxicam, a non-opioid analgesic of the NSAID group, was started at the dose of $7.5 \mathrm{mg}$ per day combined with drotaverine. Relief of pain was achieved. Computed tomography performed after the $6^{\text {th }}$ cycle of the treatment revealed a stable disease according to RECIST 1.1 criteria. A decision was made to continue the treatment using the same regimen. During the second day of the $7^{\text {th }}$ cycle, the patient experienced strong dull pain in the hypogastrium, projecting at the location of the tumour infiltrating the pelvic organs (NRS 7-8/10), diffuse in the mesogastrium and the epigastrium, with girdle pain at the projection point for the enlarged liver and the lymph nodes. Due to the lack of pain control and the intensity of the pain the decision was made, on an emergency basis, to administer intravenous morphine. Stabilisation of symptoms was achieved after titrating the dose of adjuvant medication, due to the neuropathic component of pain (intravenous valproate $400 \mathrm{mg}$, mianserin $10 \mathrm{mg}$ PO, drotaverine $40 \mathrm{mg} \mathrm{IV}$ ) and the start of the prophylactic anti-constipation regimen. The dose of morphine administered intravenously with an infusion pump was $20 \mathrm{mg}$ per 24 hours. In the following days the route of the morphine administration was changed to subcutaneous, at the dose of $30 \mathrm{mg} / 24$ hours in divided doses administered every 4 hours, which, converted into the form of an oral dose, was equal to a dose of $60 \mathrm{mg}$ per day, administered in two divided doses. In addition, a short-acting formulation of morphine sulphate was recommended in the event of breakthrough pain (BTP). Eight days after the discharge, the patient came to the Oncology Outpatient Clinic because of exacerbation of pain, with a similar nature and location in the abdomen area. After clarifying the medical history, the patient was found to suffer from an "end of dose pain". During the outpatient visit, the dose of controlled release morphine was modified by increasing the daily dose by approx. 50\% (compared to the previously 
prescribed dose of morphine administered orally) to $90 \mathrm{mg}$ in three divided doses (a controlled release tablet, $30 \mathrm{mg}$ every 8 hours). After completing check-ups, including liver parameters (metastatic lesions in the liver, history of chronic hepatitis B) the treatment was supplemented with a daily dose of paracetamol $-2 \mathrm{~g}$. The patient remained in constant contact with his doctor. During a two-week period, as reported by the patient, the pain control was satisfactory. After this period, the patient reported at the time of the planned $8^{\text {th }}$ cycle chemotherapy; the patient did not complain about pain at the time of admission. On the third day of hospitalisation, he reported worsening of pain control in the hypogastrium, mesogastrium, and epigastrium, with pain of girdle nature (NRS 7-8/10), and paroxysmal pain with persistent urinary urgency after voiding (NRS 7/10), with accompanying burning at the projection point of the bladder and incomplete emptying of the bladder. The patient was consulted with a palliative care specialist. While analysing the case of the patient, the nature of the pain (nociceptive pain in a visceral location, with neuropathic component), the intensity of the pain, and the pharmacokinetic-pharmacodynamic profile of analgesics, it was found that it would be beneficial to switch the opioids and replace morphine with oxycodone. Intravenous oxycodone was administered with an infusion pump in the dose of $1.2 \mathrm{mg} /$ hour (the initial dose was reduced by approx. 30\% compared to the previously prescribed daily dose of morphine in the infusion pump).

Eventually, $1.7 \mathrm{mg} / \mathrm{h}$ of oxycodone was titrated with an infusion pump. Given the scheduled discharge and continuation of treatment at home, the route of opioid administration was changed from intravenous to oral, with the daily dose of $120 \mathrm{mg}$ per day administered in two divided doses.

Due to lack of sufficient neuropathic pain control (burning at the projection point of the bladder NRS 3/10), the treatment was supplemented with pregabalin (initial dose of $75 \mathrm{mg}$ /day, gradually increased to $150 \mathrm{mg}$ /day). Satisfactory pain control was achieved, which made it possible to continue the systemic therapy. During subsequent visits by the patient to the Department of Oncology within the next eight weeks, the daily dose was gradually increased to $200 \mathrm{mg}$ of controlled release oxycodone, due to worsening pain control. A non-opioid analgesic (paracetamol, $2 \mathrm{~g} /$ day) and pregabalin (150 mg/day) were continued, as well as a prophylactic anti-constipation regimen using an osmotically active drug (lactulose). Additionally, it was recommended to use a short-acting formulation of oxycodone hydrochloride in oral solution, in case of breakthrough pain, in the dose of $30 \mathrm{mg}(1 \mathrm{mg} / \mathrm{ml})$, which is equal to $1 / 6^{\text {th }}$ of the primary dose.

It must be emphasised that the patient, despite the administration of such large doses of oxycodone, had no impairment of consciousness, and no adverse reactions were observed of a nature that might be expected from the strong opioids.

Re-aggravation of pain occurred two days before the administration of chemotherapy cycle 11 . On admission to the Department of Oncology, the patient reported end of dose pain (nociceptive pain in a visceral location) with in- tensity equal to NRS 4-5/10. The analgesia was modified, with an increase of the daily dose in controlled release tablets to $300 \mathrm{mg}$ (a dose of $100 \mathrm{mg}$ every 8 hours). There was no deterioration of consciousness. The patient was also given a preparation of transmucosal fentanyl, with buccal administration in a titrated dose of $100 \mu \mathrm{g}$ in case of BTP. The treatment with pregabalin, non-opioid analgesic, and prophylactic anti-constipation regimen was continued. A very good analgesic effect was achieved and the patient did not require any modification of the analgesic treatment in the course of further systemic therapy.

Chemotherapy was continued until the $7^{\text {th }}$ cycle; the imaging studies performed after completion of the systemic treatment revealed disease progression, and cachexia was observed, with the deterioration of general condition, which was reflected in the results of laboratory tests (hypoalbuminaemia, increased activity of the lactate dehydrogenase, increased concentration of the carcinoembryonic antigen). The patient was disqualified from further systemic therapy and referred for treatment within a hospice at home.

\section{Discussion}

Visceral pain is a significant problem in the practice of clinicians dealing with cancer patients, with the pain of this nature found in approx. $30 \%$ of patients. It is most often associated with advanced malignancy, such as pancreatic carcinoma, gastric carcinoma, and colorectal carcinoma and the presence of metastases in the liver, retroperitoneal lymph nodes, peritoneum, and mesentery. The symptoms may result from the presence of the tumour, as well as the ensuing sub- or obstruction. Reported symptoms most often include poorly localised pain of a burning, gripping, and cramp-like nature. It is also often accompanied by autonomic symptoms, such as nausea, vomiting, and increased sweating. Currently, treatment guidelines do not identify visceral pain as requiring different therapeutic approaches, and the recommended procedure is no different from that for somatic pain. Clinical practice shows, however, that knowledge of the pathogenesis of visceral pain and the differences in the pharmacodynamics and pharmacokinetics of available analgesic drugs make it possible to optimise the treatment of visceral pain. In the treatment of visceral pain, due to the location of the opioid receptors, the preferred drugs are opioid receptor agonists of mixed $\mu$ and $\kappa$ type.

Oxycodone is a semi-synthetic derivative of thebaine. The main mechanism of action of oxycodone is associated with stimulation of the peripheral and central opioid receptors of the $\mu$ and $\kappa$ type. It is thought that $\kappa$ receptors constitute an essential part in the analgesic mechanism of action of oxycodone [1]. Opioid receptors of the $\kappa$ type are involved in the mechanisms of visceral pain formation, and hence the drug has high therapeutic efficacy, particularly in visceral location of pain [1]. By interacting with the G-protein, oxycodone causes the potassium channels to open and blocks activation of voltage-dependent calcium channels. The consequence of the described effects is a reduction of the excitability of nerve cells. Although oxy- 
codone - compared with morphine - has lower intrinsic activity in relation to the $\mu$-type receptor, its analgesic effect is stronger [1-4]. This is due to the fact that, at comparable concentrations in the blood of both opioid analgesics, the concentration of unbound oxycodone in the brain is sixfold higher compared with morphine. In the treatment of cancer pain, oxycodone is characterised by optimal pharmacokinetic profile and a high safety profile in patients concomitantly treated with other drugs. The interactions due to inhibition of CYP3A4 and CYP2D6 activity by other drugs have virtually no clinical significance $[1,5,6]$. Clinically significant interactions may be associated with concomitant administration of drugs: depressants of central nervous system functions and anticholinergic drugs.

Oxycodone, administered orally, is about twice as strong as morphine, is administered parenterally, and is only slightly stronger; the coefficient of equivalent doses of intravenous morphine relative to oxycodone is on the level of 1:0.7. In clinical practice, however, it has been observed that in patients with visceral pain locations, similar parenteral doses of oxycodone and morphine are often needed. It is worth mentioning that the most effective method to determine adequate oxycodone doses in relation to the present pain is titrating the dose. If the patient experiences pain of high intensity and has not been previously treated with a strong opioid, titration starts with an intravenous bolus. It is advisable, depending on the intensity of pain, to perform slow administration of 1-2 mg of oxycodone every 5 minutes [1]. If, for example, the oxycodone dose needed to achieve effective analgesia is titrated at 8 $\mathrm{mg}$, the patient should receive a continuous intravenous infusion of oxycodone in the dose of $1 \mathrm{mg} /$ hour (half-life equal to approx. 4 hours means that in that time a half of the dose, or $4 \mathrm{mg}$, must be administered to maintain constant therapeutic concentration of the drug). In the case of an alternative use of subcutaneous, the initial daily dose of oxycodone should be equal to $7.5 \mathrm{mg}$ [6]. Oxycodone is available as an oral formulation (OxyNorm ${ }^{\circledR}$ oral solution - as a fast-acting preparation and controlled-release tablets OxyContin ${ }^{\mathrm{TM}}$ with the AcroContin ${ }^{\mathrm{TM}}$ system providing biphasic release of the drug) and in a form intended for parenteral administration (OxyNorm ${ }^{\circledR}$ ampoules). What is also important is the fact that an innovative oral formulation is available on the pharmaceutical market, which is a combination of oxycodone with naloxone (Targin $\left.{ }^{\circledR}\right)[1,2$, 7], recommended for patients with pain and constipation after treatment with opioids.

The literature contains few works on the use of high doses of oxycodone in the treatment of cancer pain. In 2011, Mercadante et al. published the results of an analysis of 212 patients who used controlled-release oxycodone as the primary analgesic [8]. Patients were assigned to one of three groups: in the first group, 129 patients were treated with the daily dose of less than $120 \mathrm{mg}$; in the next group, 43 patients received higher daily doses of 120-240 mg; and in the last group, 40 patients received the drug in the dose of $240 \mathrm{mg} /$ day. The mean daily dose of oral oxycodone was $141 \pm 167 \mathrm{mg}$ (dose range $10-960 \mathrm{mg}$ ), and in the individual groups it was equal to $48.4 \pm 25 \mathrm{mg}, 156.5 \pm 30.5$ $\mathrm{mg}$, and $435 \pm 196 \mathrm{mg}$, respectively. In this study, there was no difference in terms of gender, primary diagnosis, and the mechanism of pain. Adverse reactions were mild and were not associated with the administered dose of oxycodone. The authors concluded that at high doses, the oxycodone drug is safe and effective $[8,9]$.

In conclusion, oxycodone is a valuable alternative in the treatment of pain in cancer patients. Compared to morphine, oxycodone has a different receptor profile, including the impact on kappa opioid receptors, which may be of particular significance in the treatment of neuropathic and visceral pain. Other features that characterise oxycodone include high bioavailability, metabolism to inactive metabolites, little risk of interaction with other concomitantly used drugs, optimum safety profile compared to other opioids, and minimal immunosuppressive activity $[10,11]$.

\section{Collaboration with Mundipharma Polska.}

\section{References}

1. Dobrogowski J, Wordliczek J, Woroń J. Oksykodon, Opioidowe leki przeciwbólowe w farmakoterapii bólu. In: Farmakoterapia bólu. Termedia, Poznań 2014; 78-81.

2. Filipczak-Bryniarska I, Woroń J, Strzępek K, Bryniarski K, Wordliczek J. Zastosowanie oksykodonu u pacjentów z bólem towarzyszącym chorobie nowotworowej - opis przypadku. Anestezjologia i Ratownictwo 2013; 7: 173-178.

3. Woroń J, Filipczak-Bryniarska I, Dobrogowski J, Wordliczek J. Oksykodon trafny wybór w farmakoterapii bólu. Anestezjologia i Ratownictwo 2011; 5: 468-472.

4. Dzierżanowski T, Ciałkowska-Rysz A. Oksykodon - lek pierwszego rzutu w leczeniu silnego bólu nowotworowego. Med Paliat 2010; 3: 123-131.

5. Lalovic B, Kharasch E, Hoffer C, Risler L, Liu-Chen LY, Shen DD. Pharmacokinetics and pharmacodynamics of oral oxycodone in healthy human subjects: role of circulating active metabolites. Clin Pharmacol Ther 2006; 79: 461-79.

6. Oxycodone. In: Palliative Care Formulary 5th Edition. Twycross R, Wilcock A (eds.). Accessed online: www.palliativedrugs.com on.

7. Dzierżanowski T, Ciałkowska-Rysz A. Zastosowanie oksykodonu z naloksonem w formie tabletek o przedłużonym uwalnianiu jako leku opioidowego pierwszego rzutu u chorej z ciężkim zaparciem stolca i silnym bólem - opis przypadku. Med Paliat 2013; 5: 180-184.

8. Mercadante S, Ferrera P, David F, Casuccio A. The use of high doses of oxycodone in an acute palliative care unit. Am J Hosp Palliat Care 2011; 28: 242-244

9. Leppert W, Werner S. Zastosowanie wysokiej dawki oksykodonu o kontrolowanym uwalnianiu po zmianie z doustnej morfiny opis przypadku. Contemp Oncol (Pozn) 2011; 15: 337-340.

10. Vallejo R, De Leon-Casasola O, Benyamin R. Opioid therapy and immunosuppression. Am J Therap 2004; 11: 354-365.

11. Budd K. Pain management: is opioid immunosuppression a clinical problem? Biomed and Pharmacother 2006; 60: 310-317.

\section{Address for correspondence}

Jakub Kucharz MD PhD

Department of Clinical Oncology, University Hospital in Krakow

Śniadeckich 10

31-531 Krakow, Poland

tel. +48124248912

$\mathrm{fax}+48124248910$

e-mail: jakub.kucharz@uj.edu.pl 